


PUCPR

\title{
Population biology of $U c a$ mordax (Smith, 1870) (Crustacea, Decapoda, Ocypodidae) from the southeastern coast of Brazil
}

\author{
Biologia populacional de Uca mordax (Smith, 1870) (Crustacea, \\ Decapoda, Ocypodidae) do litoral sudeste do Brasil
}

\author{
Vivian Fransozo $^{[a]}$, Rafael Campanelli Mortari ${ }^{[\mathrm{b}]}$, Aline Staskowian Benetti ${ }^{[\mathrm{c}]}$
}

[a] Biologist, Msc., Departamento de Zoologia, Universidade Estadual Paulista (UNESP), Botucatu, SP - Brasil, e-mail: vifransozo@ibb.unesp.br

[b] Biologist, Msc., Departamento de Zoologia, Universidade Estadual Paulista (UNESP), Botucatu, SP - Brasil, e-mail: rafamortari@hotmail.com

[c] Biologist, Doctor, Museu de Zoologia, Universidade de São Paulo (MZUSP), São Paulo, SP - Brasil, email: alinebenetti@usp.br

\begin{abstract}
The population biology of the fiddler crab Uca mordax (Smith, 1870) was investigated in an estuarine mangrove from the southeastern coast of Brazil. Samplings were monthly performed by 2 collectors for 30 min. using the technique of capture per unit effort during low tide periods. The allometric technique was used to determine crab size at sexual maturity (males and females). Thus, specimens were classified into juveniles and adults according to their size at sexual maturity for each sex. The specimens were distributed into size classes. Recruitment was based on the juvenile frequency and the reproduction peak in ovigerous females. The median size of males was $15.9 \pm 2.7 \mathrm{~mm}$ carapace width $(\mathrm{CW})(\mathrm{n}=557)$ and

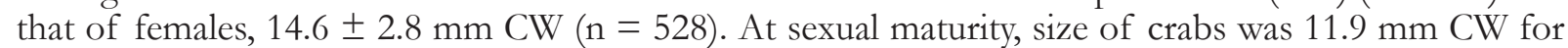
males and $11.5 \mathrm{~mm} \mathrm{CW}$ for females. Juveniles were found throughout the year but more frequently in the winter and autumn. Sex ratio did not differ among seasons, except during the summer $(\mathrm{p}<0.05)$. As regards sex ratio per size class, females predominated in the first size classes. Reproduction peak was observed in the summer. In short, the population biology of U. mordax was similar to that of most broad-front fiddler crab species.
\end{abstract}

Keywords: Fiddler crab. Maturity sexual. Recruitment. Sex ratio. Size distribution frequency. 


\section{Resumo}

A biologia populacional do caranguejo violinista Uca mordax (Smith, 1870) foi estudada em um manguezal estuarino do litoral sudeste do Brasil. As amostragens foram efetuadas mensalmente por meio da técnica de esforço de captura por dois coletores durante 30 minutos, em período de maré baixa. A técnica alométrica foi utilizada para determinar o tamanho no qual os caranguejos (machos e fêmeas) atingem a maturidade sexual morfológica. Os caranguejos foram classificados em juvenis ou adultos, de acordo com o seu tamanho, na maturidade sexual para cada sexo. Os espécimes foram distribuídos em classes de tamanho. O recrutamento baseou-se na frequência de juvenis e o período reprodutivo, na frequência de fêmeas ovígeras. O tamanho mediano obtido para os machos foi de 15,9 $\pm 2,7 \mathrm{~mm}$ de largura de carapaça $(n=557)$ e, para as fêmeas, foi de $14,6 \pm 2,8 \mathrm{~mm}$ de CW $(n=528)$. O tamanho da maturidade sexual morfológica em machos é de 11,9 $\mathrm{mm}$ de largura de carapaça e, para as fêmeas, é de 11,5 mm de LC. Os juvenis foram encontrados ao longo de todo o ano, mas com maior intensidade durante o inverno e o outono. A razão sexual não difere ao longo das estações, exceto durante o verão $(p<0,05)$. Com relação à razão sexual em classes de tamanho, as fêmeas predominam nas primeiras classes. O pico reprodutivo mais evidente foi verificado no verão. De modo geral, U. mordax apresenta características populacionais semelhantes à maioria das espécies de caranguejos violinistas com fronte larga.

Palavras-chave: Caranguejo violinista. Frequência de distribuição de tamanho. Maturidade sexual. Razão sexual. Taxa de recrutamento.

\section{Introduction}

Morphological changes in crabs of the genus Uca Leach, 1814 have been reported by many authors $(1,2,3,4,5,6,7)$. According to (8), the variations in the growth pattern of certain organs or their parts relative to others in the same individual, or the differences between sexes within one same species as well as among different species, have biological significance. Such changes can mainly occur in the chelipeds, abdomen and pleopods of crabs and are more evident between sexes and juvenile $v$ s. adult phases (9).

The onset of sexual maturity is a biological event of great importance for crabs since it is marked by a series of morphological and physiological transformations, which lead to habit and/or behavioral changes (10). Thus, such stage should be assessed in populational studies (11), considering the great inter or intraspecific variations.

The structural characterization of a population provides basic information about the management of natural resources. In the last twenty years, papers about population biology have been more accepted by the researchers. Learning the biological and ecological aspects of a species (juvenile recruitment, growth rate, and size at onset of sexual maturity) provides more information on its birth rate, mortality, growth, migration, and reproduction $(12,13)$.
As mentioned by (14), the fiddler crab Uca mordax (Smith, 1870) is distributed in Gulf of Mexico, Central America, north of South America, Guyana, and Brazil (from Pará to São Paulo States), where it can be found in mangroves and river margins. Such author also pointed out that there is a reasonable abundance of this species at higher mangrove levels, where the water is practically freshwater.

The biology of U. mordax is poorly known. (15) studied its larval development under laboratory conditions, and (16) investigated the relative growth of a population from Guaratuba, ParanáState, Brazil.

The current study describes the relative growth of U. mordax in an estuarine mangrove from the northern coast of São Paulo State, Brazil, with the aim of indicating its size at the onset of sexual maturity. Size frequency distribution, recruitment and sex ratio were also assessed to better understand the general biology of this species. A comparison with previous studies was also performed.

\section{Materials and methods}

Fiddler crabs were monthly collected from July 2001 to June 2002 in Itamambuca mangrove


State, Brazil. Samplings consisted in the technique 
of capture per unit effort by 2 collectors for $30 \mathrm{~min}$ during low tide periods.

Itamambuca mangrove is characterized by mangle vegetation composed exclusively of Laguncularia racemosa (Linnaeus). According to (17), tree density in Itamambuca reaches 1,250 trees per hectare, with a mean height of $4.8 \mathrm{~m}$ and mean diameter at breast height of $6 \mathrm{~cm}$. The substratum is composed of poorly sorted medium sand and the organic matter content in the sediment is higher than that in other sites of the same region (Ubatuba, São Paulo State) (18).

All obtained specimens were separated according to sex and ovigerous conditions. Then, a precision caliper $(0.01 \mathrm{~mm})$ was used for the following measures: carapace width $(\mathrm{CW})$, carapace length (CL), abdomen width (AW), propodus length (PL) and propodus height $(\mathrm{PH})$ for both sexes, and gonopod length (GL) for males. In males, we measured the major cheliped and in females, the right one.

The handedness of the major cheliped was also recorded and tested by chi-square test $(\alpha=$ $5 \%$ (19).

The mean size of specimens (CW) was compared between sexes and the mean size of the major cheliped (PL), between right and left sides through Mann-Whitney test $(\alpha=5 \%)$ as data was not normally distributed (19). Specimens in preand post-molt stage, with defective carapaces and without some appendages, were not included in this part of the study.

The first maturation of $U$. mordax was determined through the alometric technique, using the software Mature I and Mature II $(20,21)$. The algometric equation $\mathrm{Y}=\mathrm{a} \mathrm{X}^{\mathrm{b}}(22)$ was adjusted to the dispersion points of juvenile and adult crabs.

Carapace width (CW) was adopted as the independent variable $(\mathrm{X})$ and related to other body dimensions (dependent variables - Y): CL, AW, PL, $\mathrm{PH}$, and CG. The allometric coefficient (b) represents the allometric degree of the studied body part. The statistical significance of the allometric coefficient was verified through Student's $t$-test at $5 \%$ level $\left(\mathrm{H}_{0}\right.$ : $\mathrm{b}=1)$. Then, all the obtained equations were linearized. The intercepts and the slopes of the straight lines in each development phase were compared by means of covariance analysis $(\alpha=5 \%)(19)$.

The population structure was analyzed by season, grouping the data into $10 \mathrm{CW}$ size classes ( $2 \mathrm{~mm}$ wide) according to demographic categories.
The normality of distributions was tested through Shapiro-Wilk test $(\alpha=5 \%)$ (19) and the homoscedasticity by means of Levene test $(\alpha=5 \%$ ) (19).

Recruitment was defined as the juvenile rate in each season, considering juveniles those specimens of smaller size than that at the first sexual maturity for each sex, which was obtained through the allometric technique. The juvenile rate was compared among seasons by using multinomial proportion test complemented with Tukey's test (MANAP; $\alpha=$ $5 \%)(23)$.

Sex ratio was analyzed for each month and size class. A chi-square test for goodness of fit $\left(\mathrm{X}^{2}\right.$; $\alpha=5 \%$ ) (19) was used to evaluate the sex ratio and compare the monthly percentages of males and females.

\section{Results}

During the sampling period we obtained 1,085 U. mordax specimens, of which 557 were males and 528 females (14 ovigerous crabs). For relative growth assessment and size determination at the onset of sexual maturity, only 372 males and 280 females were used as they were in intermolt stage and had no defective body parts or appendages.

Total crab size varied from 4.9 to $22.9 \mathrm{~mm}$ $(15.9 \pm 2.7) \mathrm{CW}$ for males and from 4.3 to $20.8 \mathrm{~mm}$ $(14.6 \pm 2.8) \mathrm{CW}$ for females. The smallest ovigerous females were $12.9 \mathrm{~mm} \mathrm{CW}$, whereas the largest ones measured $20.8 \mathrm{~mm} \mathrm{CW}$.

Males reached larger mean sizes $(16.4 \mathrm{~mm})$ than females $(15.3 \mathrm{~mm})(\mathrm{p}<0.05)$. The rate of males with greater chelipeds on the right side was $51.75 \%$ $(p>0.05)$. All the obtained relationships between body parts were tested to determine the size at the onset of sexual maturity and those showing the best adjustment and most clear change from juvenile to adult phase were: CW vs. PL for males and CW vs. AW for females.

Males became sexually mature at $11.9 \mathrm{~mm}$ $\mathrm{CW}$ and females at $11.5 \mathrm{~mm} \mathrm{CW}$ (Figure 1). The allometric equations for U. mordax are presented in Table 1.

The frequency distributions by size classes per season are represented in Figure 2. Juveniles were present throughout the year but at higher frequencies during the winter and autumn (Figure 3), indicating a recruitment period in such seasons. 



Figure 1 - U. mordax. Dispersion points and adjusted curve for the relationship CW vs. PL for males (A) and CW vs. AW for females (B) (closed cycle $=$ juvenile males and females; open cycle $=$ adult males and females; $\mathrm{CW}=$ carapace width; PL = cheliped propodus length; AW = abdomen width)

Source: Research data.

Table 1 - Results of the regressions obtained for the U. mordax (Smith, 1870) population from Itamambuca mangrove. Carapace width $(\mathrm{CW})$ was used as the independent variable

\begin{tabular}{|c|c|c|c|c|c|c|c|c|}
\hline Relationship & Category & $n$ & $\begin{array}{l}\text { Power equation } \\
\qquad\left(\mathrm{Y}=\mathrm{aX}^{\mathrm{b}}\right)\end{array}$ & $\begin{array}{c}\text { Linearized equation } \\
(\log y=\log a+b \log x)\end{array}$ & $r^{2}$ & $t(\mathrm{~b}=1)$ & $\begin{array}{c}\text { Allometry } \\
\text { level }\end{array}$ & $\begin{array}{c}\text { Cut } \\
\text { point } \\
\text { CW }\end{array}$ \\
\hline \multirow{4}{*}{ CL } & JM & 35 & $\mathrm{CL}=0.768 \mathrm{CW}^{0.9748}$ & $\log C W=-0.114+0.974 \log C L$ & 0.975 & 0.96 & 0 & \\
\hline & $\mathrm{AM}$ & 398 & $\mathrm{CL}=0.881 \mathrm{CW}^{0.9219}$ & $\mathrm{Log} C W=-0.055+0.921 \log C L$ & 0.933 & $6.58^{*}$ & - & \\
\hline & JF & 61 & $\mathrm{CL}=0.767 \mathrm{CW}^{0.9789}$ & $\log C W=-0.115+0.978 \log C L$ & 0.969 & 1.00 & 0 & \\
\hline & $\mathrm{AF}$ & 399 & $\mathrm{CL}=0.731 \mathrm{CW}^{1.0004}$ & $\log C W=-0.130+1.000 \log C L$ & 0.954 & 0.04 & 0 & \\
\hline \multirow{3}{*}{ AW } & TM (ns) & 432 & $\mathrm{AW}=0.395 \mathrm{CW}^{0.8480}$ & $\log C W=-0.403+0.848 \log A W$ & 0.915 & $12.66^{*}$ & - & \\
\hline & JF & 56 & $\mathrm{AW}=0.096 \mathrm{CW}^{1.6816}$ & $\log C W=-1.017+1.681 \log \mathrm{AW}$ & 0.897 & $7.71 *$ & + & $11.5 \mathrm{~mm}$ \\
\hline & $\mathrm{AF}$ & 388 & $\mathrm{AW}=0.194 \mathrm{CW}^{1.4266}$ & $\log C W=-0.712+1.426 \log \mathrm{AW}$ & 0.893 & $18.80^{*}$ & + & \\
\hline \multirow{3}{*}{ PL } & JM & 35 & $\mathrm{PL}=0.179 \mathrm{CW}^{1.6549}$ & $\mathrm{Log} C W=-0.747+1.649 \log \mathrm{PL}$ & 0.901 & $7.92 *$ & + & \\
\hline & $\mathrm{AM}$ & 359 & $\mathrm{PL}=0.043 \mathrm{CW}^{2.2402}$ & $\log C W=-1.366+2.240 \log \mathrm{PL}$ & 0.795 & $22.42^{*}$ & + & $11.9 \mathrm{~mm}$ \\
\hline & $\mathrm{TF}$ (ns) & 449 & $\mathrm{PL}=0.435 \mathrm{CW}^{0.9332}$ & $\mathrm{Log} C W=-0.361+0.933 \log \mathrm{PL}$ & 0.908 & $5.15^{*}$ & - & \\
\hline \multirow{2}{*}{ PH } & TM (ns) & 408 & $\mathrm{PH}=0.091 \mathrm{CW}^{1.6136}$ & $\log \mathrm{CW}=-1.040+1.613 \log \mathrm{PH}$ & 0.934 & $29.1 *$ & + & \\
\hline & TF (ns) & 455 & $\mathrm{PH}=0.193 \mathrm{CW}^{0.7783}$ & $\mathrm{Log} C W=-0.713+0.778 \log \mathrm{PH}$ & 0.777 & $11.68^{*}$ & - & \\
\hline \multirow{2}{*}{ GL } & JM & 33 & $\mathrm{GL}=0.191 \mathrm{CW}^{1.3050}$ & $\log C W=-0.718+1.305 \log G L$ & 0.908 & $4.12^{*}$ & + & \\
\hline & $\mathrm{AM}$ & 401 & $\mathrm{GL}=0.509 \mathrm{CW}^{0.9099}$ & $\log C W=-0.293+0.909 \log G L$ & 0.720 & $3.28^{*}$ & - & \\
\hline
\end{tabular}

Note: $*=$ ns means that juvenile and adult categories did not differ concerning growth rate, thus they were grouped $(\mathrm{CL}=\mathrm{carapace}$ length; $\mathrm{CW}=$ carapace width; $\mathrm{AW}=$ abdomen width; $\mathrm{PL}=$ cheliped propodus length $\mathrm{PH}=$ cheliped propodus height; $\mathrm{GL}=$ gonopod length; JM = juvenile male; $\mathrm{AM}=$ adult male; $\mathrm{TM}=$ total male; $\mathrm{JF}=$ juvenile female; $\mathrm{AF}=$ adult female; $\mathrm{TF}=$ total female; $n=$ number of specimens; $0=$ isometry; $+=$ positive allometry; $-=$ negative allometry; $\mathrm{ns}=$ non significant; $*=$ significant by Student's $t$-test $(\mathrm{p}<0.05) ; \mathrm{r}^{2}=$ determination coefficient $)$ Source: Research data. 


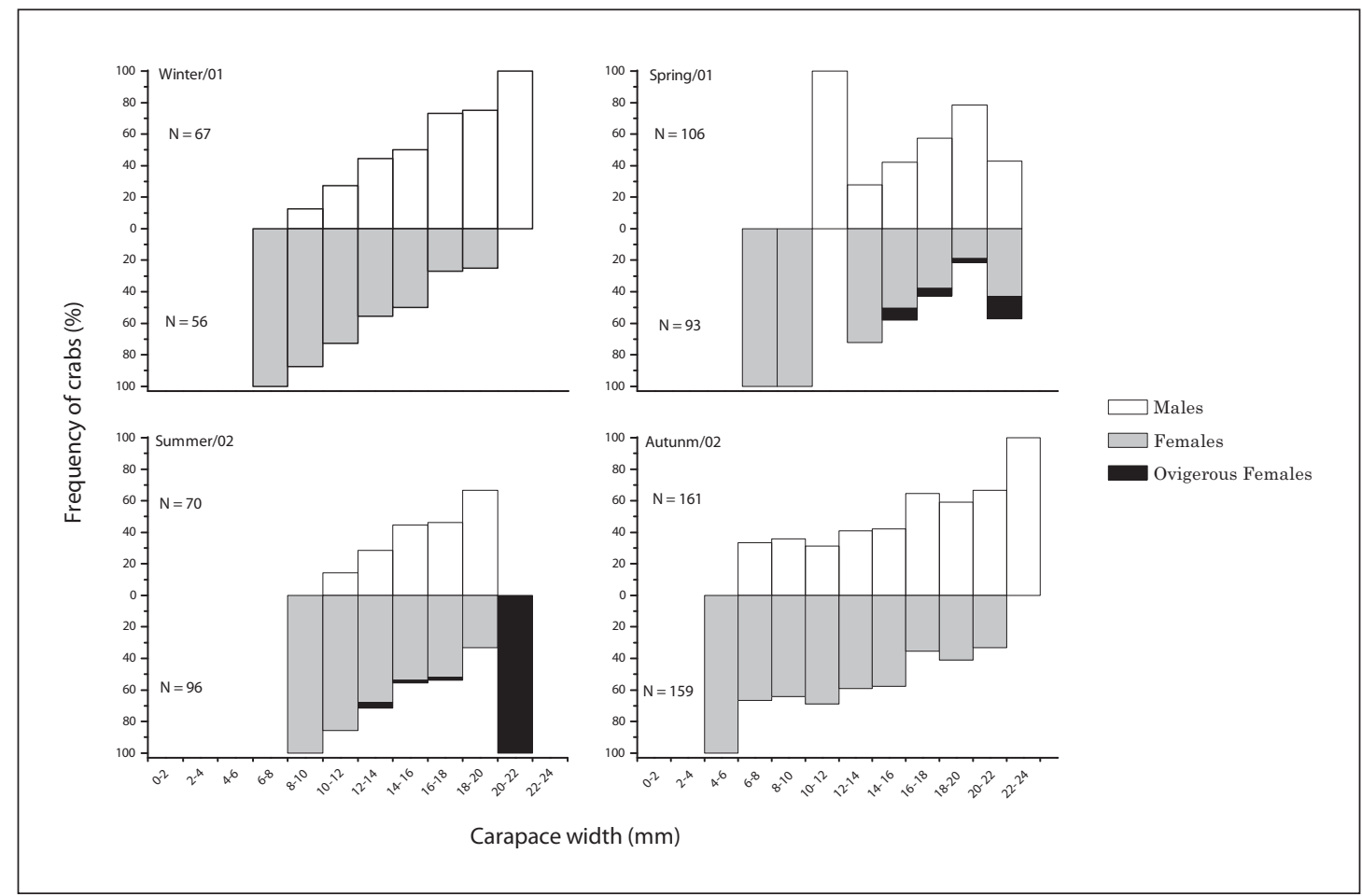

Figure 2 - U. mordax. Frequency distribution histogram by size classes carapace width ( $\mathrm{mm}$ ) in each demographic category

Source: Research data.

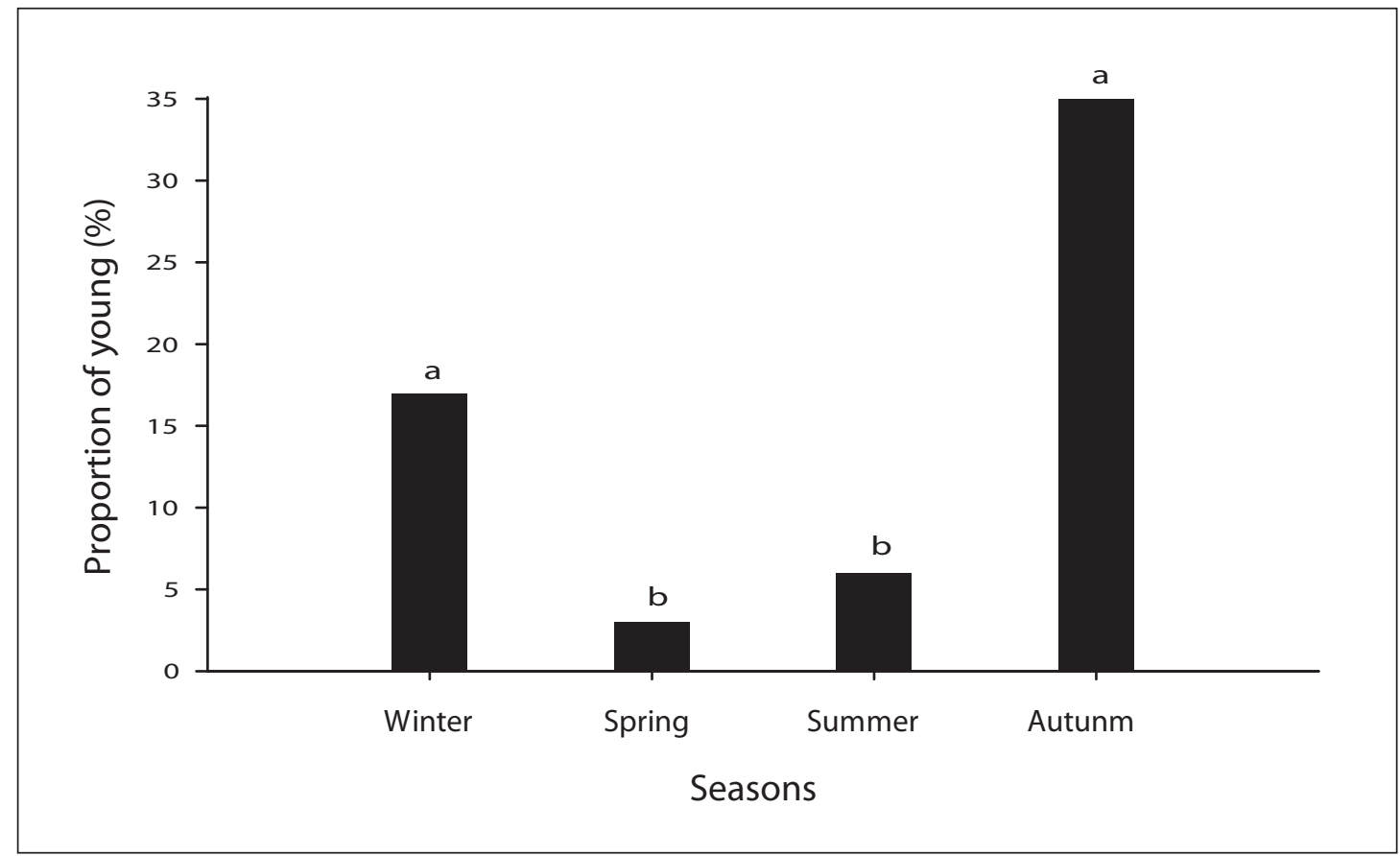

Figure 3 - U. mordax. Recruitment ratio of U. mordax in the Itamambuca mangrove throughout a year period. Bars with at least one same letter in common did not differ statistically $(\mathrm{p}>0.05)$ Source: Research data. 
Sex ratio did not differ among months $(\mathrm{p}>$ 0.05), except for January 2002 ( $\mathrm{p}<0.05)$ (Figure 4). As regards size classes, females predominated in the initial classes, whereas males prevailed in the intermediate and final classes, except in class 20-22 mm CW (Figure 5).

\section{Discussion}

Sexual maturity represents an important biological event characterized by morphological and physiological changes that can be caused by environmental or behavioral alterations (10).

As mentioned by (24) and (25), the relationships CW vs. PL and CW vs. AW for males and females, respectively, best evidenced the morphological sexual maturity of crabs, which can be exemplified by the $U$. mordax population in Itamambuca mangrove.

Uca mordax population in Guaratuba Bay, studied by (16), reached the maximum sizes of 20.0 $\mathrm{mm} \mathrm{CW}$ (males) and $18.5 \mathrm{~mm} \mathrm{CW}$ (females). These

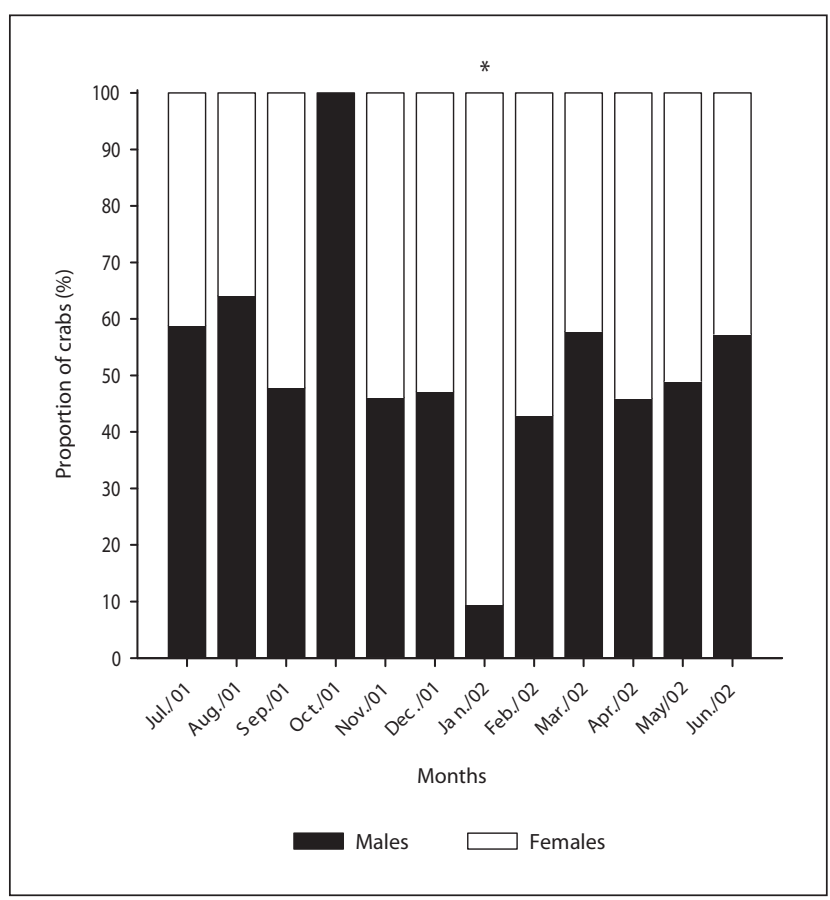

Figure 4 - U. mordax. Sex ratio by months for population from Itamambuca. Asterisks above the columns indicate significant differences between the proportions of males and females $(\mathrm{p}<0.05)$

Source: Research data. values are slightly lower than those obtained in the present study $(22.9 \mathrm{~mm} \mathrm{CW}$ for males and $20.8 \mathrm{~mm}$ CW for females). At sexual maturity, males had similar sizes in both places but females from Itamambuca, São Paulo State, were larger $(11.5 \mathrm{~mm} \mathrm{CW})$ than those from Guaratuba, Paraná State $(8.77 \mathrm{~mm} \mathrm{CW})$. The size of the smallest ovigerous females from Itamambuca $(12.9 \mathrm{~mm} \mathrm{CW})$ was similar to that at sexual maturity, according to the mean relative growth (11.5 mm CW), supporting our results.

Size differences between these two $U$. mordax populations may be due to latitude effects, as stated by (26). Such effects could also be caused by the differences in the food availability and habitat features $(7,17)$.

Recruitment is year-round and peaks were mainly observed during autumn-winter-spring for most of the previously studied species. Reproduction peak occurs during summer for U. mordax (16), U. thayeri Rathbun, 1900 (27), U. burgersi Holthuis, 1967 (24) and U. vocator (Herbst, 1804) (17); late-springsummer for U. rapax (Smith, 1870) $(18,25)$.

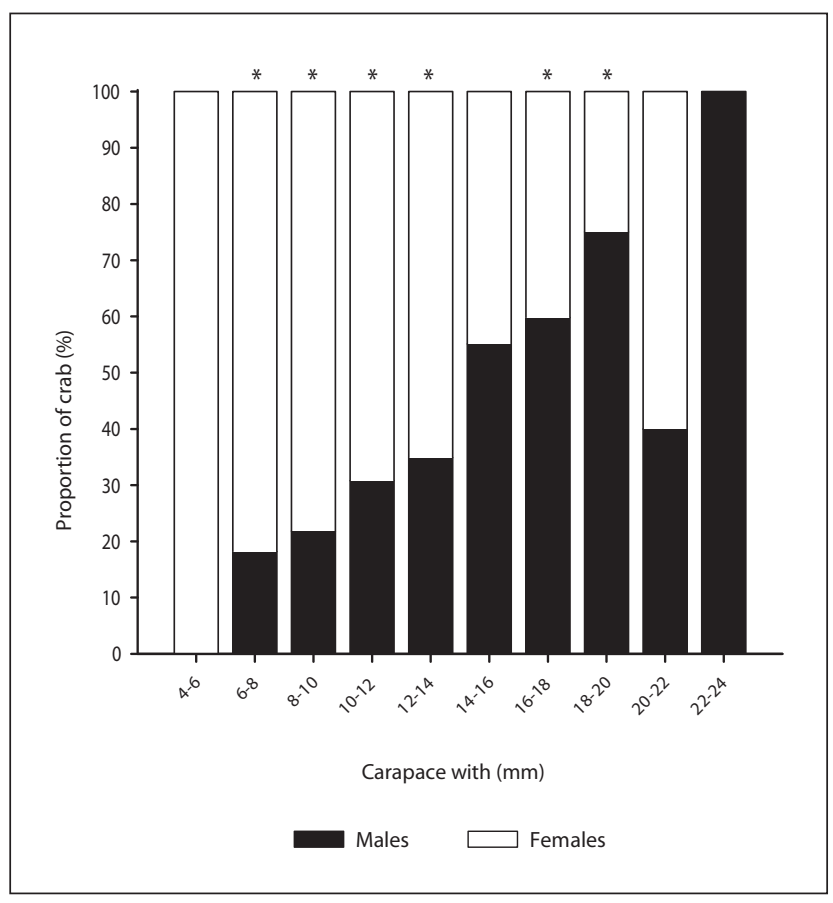

Figure 5 - U. mordax. Sex ratio by size classes of carapace width (mm) for population from Itamambuca. Asterisks above the columns indicate significant differences between the proportions of males and females $(p<0.05)$

Source: Research data. 
Allometric studies performed by (28), (29) and (2) demonstrated that throughout the ocypodid life cheliped growth in males has a direct relationship with morphological sexual maturity. This is also observed in U. mordax, which shows a positive allometry concerning the relationship CW vs. PL.

Abdominal width growth is generally used to characterize the sexual dimorphism in representatives of the infraorder Brachyura. Similarly to $U$. mordax, the relationship CW vs. AW in males has presented negative allometry, since these structures have the function of protecting the gonopods in males (30). A similar pattern was found in U. burgersi by (31), Eriphia gonagra (Fabricius, 1781) by (32) and Goniopsis cruentata (Latreille, 1803) by (33).

When U. mordax mean size is compared between sexes, females show to have a smaller maximum size, probably because they spend a reasonable amount of energy for reproductive purposes $(34,35)$, whereas males invest their energy in somatic growth, consequently reaching higher sizes. Such difference could also be related to cohort and agonistic behavior, as reported by others $(36,37)$.

According to (3), the frequency distribution of cheliped laterality can vary with the population structure. In the present paper, the percentage of right chelipeds was higher but not statistically significant, which was also observed by (38) and (39).

Broad-front fiddler crabs are known to incubate their eggs inside burrows in order to protect them against extreme environmental conditions, favoring embryonic development and larval hatching synchronically (40). A small number of U. mordax ovigerous females (11) were captured during this study and most of them were found inside burrows, suggesting they keep buried while incubating.

Uca mordax recruitment showed to be continuous throughout the studied period, presenting an elevated frequency of juveniles in the autumn and winter. Such fact was also observed by (27), who mentioned that juveniles become adults during the coldest months of the year in the northern coast of São Paulo State.

The proportion of male and female crabs tends to be very close to $1: 1$. However, such relation can be influenced by a series of factors, such as life span, migration, mortality, differential growth, and sex change (40). Nevertheless, U. mordax sex ratio did not present statistical difference over seasons, except during the summer.
In short, the species $U$. mordax follows the general pattern of population biology presented by the previously studied broad-front fiddler crabs in the southeastern coast of Brazil.

\section{Acknowledgement}

To the NEBECC (Group of studies on Crustacean biology, ecology and culture) for provide technical support during the development of the present paper. The samplings are according to State and Federal laws concerning wild animals.

\section{References}

1. Somerton D. Fitting straight lines to Hiatt growth diagrams: a re-evolution. Journal du Conseil International pour l'Exploration de la Mer. 1980;39:9-15.

2. Hutchinson GE. Introducción a la ecología de poblaciones. Barcelona: Blume; 1981.

3. Pralon BGN, Negreiros-Fransozo ML. Relative growth and morphologic sexual maturity of Uca cumulanta (Crustacea: Decapoda: Ocypodidae) from a tropical Brazilian mangrove. Journal of Marine Biological Association of the United Kingdom. 2008;88(3):569-74.

4. Backwell PRY, Christy JH, Teleford SR, Jennions MD, Passmore NI. Dishonest signaling in a fiddler crab. Proceedings of the Royal Society on London. 2000;267(B):1-6.

5. Huxley JS. Relative growth and form transformation. Proceedings of Royal Society of London. 1950;137(B):465-9.

6. Goés JM, Fransozo A. Relative growth of Eriphia gonagra (Fabricius, 1781) (Crustacea, Decapoda, Xanthidae) in Ubatuba, State of São Paulo, Brazil. Nauplius. 1997;5(2):85-98.

7. Von Hagen HO. Allometric growth in two populations of Uca tangeri from the Guadalquivir estuary (Andalusia). Investigaciones Pesqueiras. 1987;51(Supl. 1):443-52.

8. Salmon M. On the reproductive behavior of the fiddler crab Uca thayeri, with comparisons of U. pugilator and $U$. vocans: evidence for behavioral convergence. Journal of Crustacean Biology. 1987;7:25-44. 
9. Gibbs PE. Notes on Uca burgesi from Barbuda, Leeward Islands. Crustaceana. 1974;27:84-91.

10. Masunari S, Dissenha N. Alometria no crescimento de Uca mordax (Smith) (Crustacea, Decapoda, Ocypodidae) na Baía de Guaratuba, Paraná, Brasil. Revista Brasileira de Zoologia. 2005;22(4):984-990.

11. Negreiros-Fransozo ML, Fransozo A, Bertini G. Reproductive cycle and recruitment period of Ocypode quadrata (Decapoda, Ocypodidae) at a sandy beach in southeastern Brazil. Journal of Crustacean Biology. 2002;22(1):157-61.

12. Hirose LG, Negreiros-Fransozo ML. Growth phases and differential growth between sexes of Uca maracoani Latreille, 1802-1803 (Crustacea, Brachyura, Ocypodidae). Gulf and Caribbean Research. 2007; 19:43-50.

13. Somerton D. A computer technique for estimating the size of sexual maturity in crabs. Canadian Journal of Fishery and Aquatic Science. 1980;37:1488-94.

14. Crane J. Crabs of the genus Uca from Venezuela. Zoologica. 1943;28:33-44.

15. Benetti AS, Negreiros-Fransozo ML. Madurez sexual morfológica del cangrejo Uca burgersi Holthuis, 1967 (Brachyura, Ocypodidae) de una área de manglar subtropical de Brasil. Universidad y Ciencia. 2003;19(37):9-16.

16. Benetti AS, Negreiros-Fransozo ML. Relative growth of Uca burgersi (Crustacea, Ocypodidae) from two mangroves in the southeastern Brazilian coast. Iheringia, Série Zoologia. 2004;94(1):67-72.

17. Warner GF. The life history of the mangrove tree crab Aratus pisonii. Journal of Zoology. 1967;53:3321-35.

18. Rieger PJ. Desenvolvimento larval de Uca (Minuca) mordax (Smidth, 1870) (Crustacea, Decapoda, Ocypodidae), em laboratório. Trabalhos Oceanográficos da Universidade Federal de Pernambuco - UFPE. 1997;25: 227-67.

19. Melo GAS. Manual de identificação dos Brachyura (Caranguejos e Siris) do litoral brasileiro. São Paulo: Plêiade; 1996.

20. Cobo VJ, Fransozo A. Relative growth of Goniopsis cruentata (Crustacea, Brachyura, Grapsidae), on the Ubatuba region, São Paulo, Brazil. Iheringia, Série Zoologia. 1998;84:21-28.
21. Costa TM, Negreiros-Fransozo ML. Population biology of Uca thayeri Rathbun, 1900 (Brachyura, Ocypodidae) in a subtropical South American mangrove area: results from transect and catch-per-unit effort techniques. Crustaceana. 2003;75(10):1201-1218.

22. Lewis EG. Relative growth and sexual maturity of Bathynectes superbus (Costa) (Decapoda:Portunidae). Journal of Natural History. 1977;11:629-643.

23. Colpo KD, Negreiros-Fransozo ML. Comparison of the population structure of the fiddler crab $U_{c a}$ vocator (Herbst, 1804) from three subtropical mangrove forests. Scientia Marina. 2003;68(1):139-146.

24. Curi PR, Moraes RV. Associação, homogeneidade e contrastes entre proporções em tabelas contendo distribuições multinomiais. Ciência e Cultura. 1981;33(5):712-22.

25. Hines AH. Geographic variation in size at maturity in brachyuran crabs. Bulletin of Marine Science. 1989;45(2):356-68.

26. Cardoso RCF, Negreiros-Fransozo ML. A comparison of the allometric growth in Uca leptodactyla (Crustacea: Brachyura: Ocypodidae) from two subtropical estuaries. Journal of the Marine Biological Association of the United Kingdom. 2004;84:733-5.

27. Frith DW, BrunenmeisterS. Fiddlercrab (Ocypodidae: Genus $U_{c a}$ ) size, allometric and male major chela handedness and morphism on a Thailand mangrove shore. Punket Marine Biological Center. Research Bulletin. 1983;29:1-16.

28. Fontelles-Filho AA. Recursos pesqueiros, biologia e dinâmica populacional. Fortaleza: Imprensa Oficial do Ceará; 1989.

29. Díaz H, Conde JE. Population dynamics and life history of the mangrove crab Aratus pisonii (Brachyura, Grapsidae) in a marine environment. Bulletin of Marine Science. 1989;45(1):14-163.

30. CastiglioniDS, Negreiros-FransozoML.Comparative analysis of the relative growth of Uca rapax (Smith) (Crustacea, Ocypodidae) from two mangroves in São Paulo, Brazil. Revista Brasileira de Zoologia. 2004;21(1):137-44.

31. Pinheiro MAA, Fransozo A. Relative growth of the speckled swimming crab Arenaeus cribrarius (Lamarck, 1818) (Crustacea, Brachyura, Portunidae) in Ubatuba coast, State of São Paulo, Brazil. Crustaceana. 1993;65:377-389. 
32. Fransozo A, Negreiros-Fransozo ML, Bertini G. Morphometric study of the ghost crab Ocypode qua$\operatorname{drata}$ (Fabricius, 1887) (Brachyura, Ocypodidae) from Ubatuba, São Paulo, Brazil. In: Escobar-Briones E, Alvarez F, editors. Modern approaches to the study of crustacea. Netherlands: Kluwer Academic; Plenum Publishers; 2002. p. 189-195.

33. YamaguchiT.Courtship behavior of a fiddlercrab, $U_{c a}$ lactea. Journal of Science Biology. 1977;10(1):13-37.

34. CastiglioniDS, Negreiros-Fransozo ML. Comparative population biology of Uca rapax (Smith, 1870) (Brachyura, Ocypodidae) from two subtropical mangrove habitats on the Brazilian coast. Journal of Natural History. 2005;39(19):1627-40.

35. Hartnoll RG. The determination of relative growth in Crustacea. Crustaceana. 1978;34(3):281-93.

36. Hartnoll RG. Growth. In: Bliss DE. The Biology of Crustacea: embryology, morphology and genetics. 2nd ed. New York: Academic Press, Inc; 1982. p. 11-196.

37. Christy JH, Salmon M. Ecology and evolution of mating systems of fiddler crabs (Genus Uca). Biological Review. 1984;59:483-509.
38. Santos S, Negreiros-Fransozo ML, Fransozo A. Estructura poblacional de Portunus spinimanus Latreille, 1819 (Crustacea, Brachyura, Portunidae) en la Enseada de la Fortaleza, Ubatuba (SP). Revista de Investigaciones Marinas. 1995;16(1-3):37-43.

39. Zar JH. Biostatistical analysis. Prentice-Hall: Upper Saddle River; 1996.

40. Wenner AM. Sex-ratio as a function of size in marine Crustacea. The American Naturalist. 1972; 106:321-50.

41. Haley SR. Relative growth and sexual maturity of the Texas Ghost Crab, Ocypode quadrata (Fabr) (Brachyura, Ocypodidae). Crustaceana. 1969;17(3):285-97.

Recebido: 16/09/2008

Received: 09/16/2008

Aprovado: 09/04/2009

Approved: 04/09/2009 